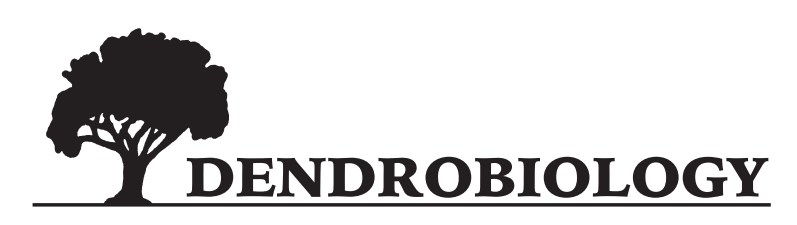

2014, vol. 72, 57-64

http://dx.doi.org/10.12657/denbio.072.005

Tomasz Maliński, Jerzy Zieliński, Piotr Kosiński

\title{
Rubus limitaneus (series Mucronati, subgenus Rubus, Rosaceae) - a species new to science from NW Poland
}

Received: 23 July 2013; Accepted: 17 February 2014

\begin{abstract}
This paper describes, illustrates, and maps a new regional bramble species occurring in the Myśliborskie Lake District in NW Poland. It represents the series Mucronati, which until now has never been recorded in this part of Europe. Locally it is the common plant and usually can be found in pine plantation established on former farmland.
\end{abstract}

Additional key words: taxonomy, variability, ecology, distribution.

Addresses: T. Maliński, University of Life Sciences, Faculty of Forestry, Department of Forest Botany, Wojska Polskiego 71d, PL-60-625 Poznań, Poland, e-mail: tomekm@up.poznan.pl

J. Zieliński, P. Kosiński, Institute of Dendrology, Polish Academy of Sciences, Parkowa 5, 62-035 Kórnik, Poland

P. Kosiński, University of Life Sciences, Department of Botany, Wojska Polskiego 71c, PL-60-625 Poznań, Poland

\section{Introduction}

An unknown bramble, described below, was found for the first time in 2003 during our field studies which were devoted to the recognition of the Rubus species in the Myśliborskie Lake District in Western Pomerania. The bramble, treated at first as a local biotype, appeared to be sufficiently widespread and common to be described as an agamic species. The genus Rubus is still rather weakly recognised in Western Pomerania. At the beginning of the $20^{\text {th }}$ century the brambles of this region were intensively studied, mainly by Holzfuss (1901, 1903, 1909, 1916, 1917, 1930). The newest, but certainly incomplete data concerning this group of plants have been gathered and recently published by the second author (Zieliński 2004).

\section{Methods}

Field studies were conducted in 2003-2011. All collected plant specimens have been deposited in the Herbarium of the Institute of Dendrology, Kórnik (KOR). The maps, detailing the distribution of the new species, were compiled using the grid squares in accordance with the principles presented in the Atlas of Distribution of Vascular Plants in Poland (Zając 1978). 


\section{Results and discussion}

\section{Rubus limitaneus T. Maliński \& J. Zieliński, species nova (Figs 1-4)}

Plant up to $1 \mathrm{~m}$ tall. Sterile stems low-arching, bluntly angled, rarely terete, distinctly patent-hairy, with long simple or tufted hairs. Prickles unequal, the largest ones $10-15$ per $5 \mathrm{~cm}, 3-5 \mathrm{~mm}$ long, broadbased, curved or straight, declining, usually with long hairs at the base, passing into (gland-tipped) needle-like prickles or acicles and stalked glands. Leaves 3-foliolate or 4-5-foliolate and then pedate, glabrous or rarely with single hairs above, softly, densely hairy beneath, with long patent shimmering hairs distinctly perceptible to the touch and most often with an underlayer of very short simple or stellate hairs. Terminal leaflets with petiolules of variable length (24-34\% of the blade), broadly elliptical to broadly obovate, cordate at base, usually short-acuminate to cuspidate, with an apex $8-15 \mathrm{~mm}$ long. Margin finely, shallowly (1-2 mm deep) serrate, often with few stalked glands; teeth broad, mucronate, principal teeth not or scarcely prominent, usually straight. Petioles usually slightly shorter than basal leaflets, usually densely patent-hairy, with straight numerous long-stalked glands, gland-tipped needle-like pricklets and stronger \pm curved, slightly declining prickles. Stipules linear-lanceolate.

Inflorescence rather short, usually narrowly conical, not many-flowered, with 3-foliolate leaves below and often with simple leaflets above. Leaflets hairy like those of the stems but with scattered hairs above. Inflorescence axis densely patent-hairy, with numerous short- and long-stalked glands and subulate, straight, patent to slightly declining prickles up to $4 \mathrm{~mm}$ long. Bracts usually numerous, filiform-linear, hairy and glandular. Pedicels variable in length, $1-2.5(-3) \mathrm{cm}$ long, densely hairy, with stalked glands longer than or as long as hairs and with straight or somewhat curved needle-like prickles up to 2(-2.5) $\mathrm{mm}$ long. Sepals grey-hairy, with numerous longstalked glands and several straight or slightly curved prickles up to $1.5(-2) \mathrm{mm}$ long, reflexed after anthesis. Petals white, elliptical or oblong-obovate, 8-10 $\mathrm{mm}$ long. Stamens longer than green styles. Anthers glabrous. Receptacle hairy. Carpels glabrous or with few long hairs.

Type: AC-52. NW Poland. Myśliborskie Lake District. Between Mieszkowice and Gozdowice, open pine forest, 52 $2^{\circ} 7^{\prime} \mathrm{N}-14^{\circ} 26^{\prime} \mathrm{E}, 26$ August 2003, leg. T. Maliński \& J. Zieliński 1/03 (holotype: Figs 1-2, KOR 49994).

Rubus limitaneus is easy to recognise by the combination of subsequent characteristics: sterile stems \pm hairy; inflorescence axis covered with unequal prick- les mixed with numerous acicles and stalked glands; leaves 3-5-foliolate; terminal leaflets rather broad, usually abruptly short-acuminate to cuspidate, with long shimmering patent hairs on the under surface and most often with an underlayer of very short stellate hairs (Fig. 2); sepals reflexed in fruit; petals elliptic; receptacle hairy. There is a great deal of variation when it comes to armature of stems, leaflets number, shape of terminal leaflets and pubescence of their lower surface. However, this variability seems to be connected with the diversity of habitats. Plants growing on richer soils are more robust, and always have 3-5-foliolate leaves. In contrast, those from less favourable sites have mostly 3 -foliolate leaves; the leaves of specimens from sunny places are characterised by especially numerous short stellate hairs on the under surface.

Rubus limitaneus belongs to the series Mucronati (Focke) Weber, which is recorded for the first time in Poland. In general, its appearance very much resembles that of $R$. mucronulatus Boreau, although it differs from the latter species with regards to its glabrous anthers and leaves which are distinctly hairy underneath. It can be distinguished from $R$. atrichantherus E. H. L. Krause by distinctly hairy stems, leaves which are hairy below and the shorter petiolules of its terminal leaflets. $R$. drejeri G. Jensen ex Lange differs from $R$. limitaneus in terms of its leaves, which are sparsely hairy beneath and a margin of leaflets with distinctly recurved principal teeth. Leaves in the new species are almost as hairy as those of $R$. hypomalacus Focke, although it has weakly armed stems and inflorescence axis.

Specimens of Rubus limitaneus which have weaker prickles on their stems and exclusively 3 -foliolate leaves can be confused with $R$. pedemontanus Pinkwart [series Glandulosi (Wimmer \& Grabowski) Focke]. With this said however, it can be separated from $R$. limitaneus by leaves subglabrous below, terminal leaflets periodically serrate, with \pm prominent, recurved principal teeth, characteristic few-flowered inflorescences and sepals patent in fruit. The stems of plants from more fertile sites are often covered with more numerous and stronger prickles as those of the species of the series Hystrix, but in contrast, the inflorescence axes of $R$. limitaneus are armed with fewer and thinner prickles.

Rubus limitaneus is a regional species grows mainly in western parts of Pomerania, in the Myśliborskie Lake District (Fig. 5). Most localities are concentrated in the south-west region of the area under study, not far from the German-Polish frontier. With this said, it is possible that it grows also on the left side of the Odra River, in Germany. The Latin epithet limitaneus - refers to the borderland area of the new species distribution. 


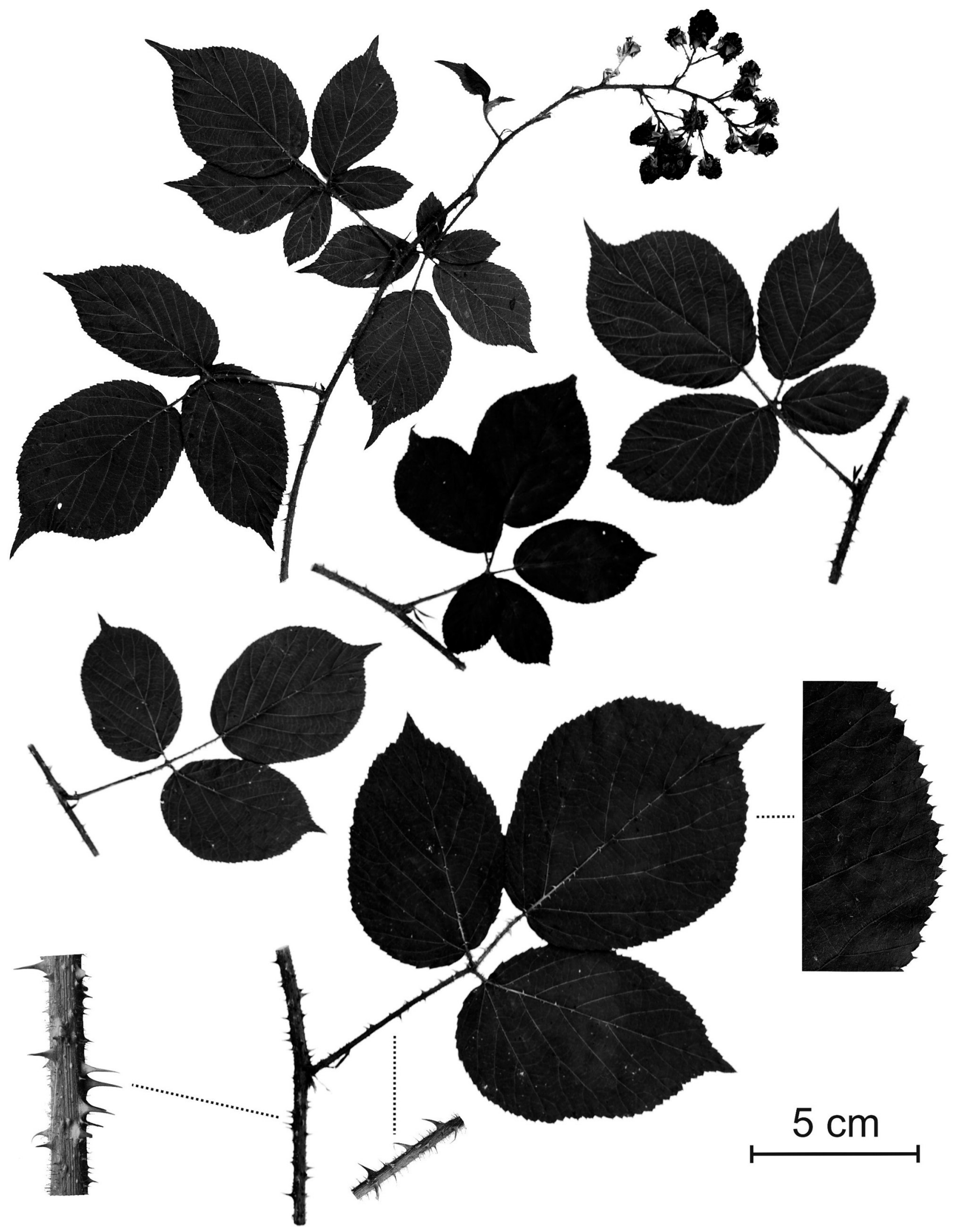

Fig. 1. Holotype of Rubus limitaneus (KOR 49994) 

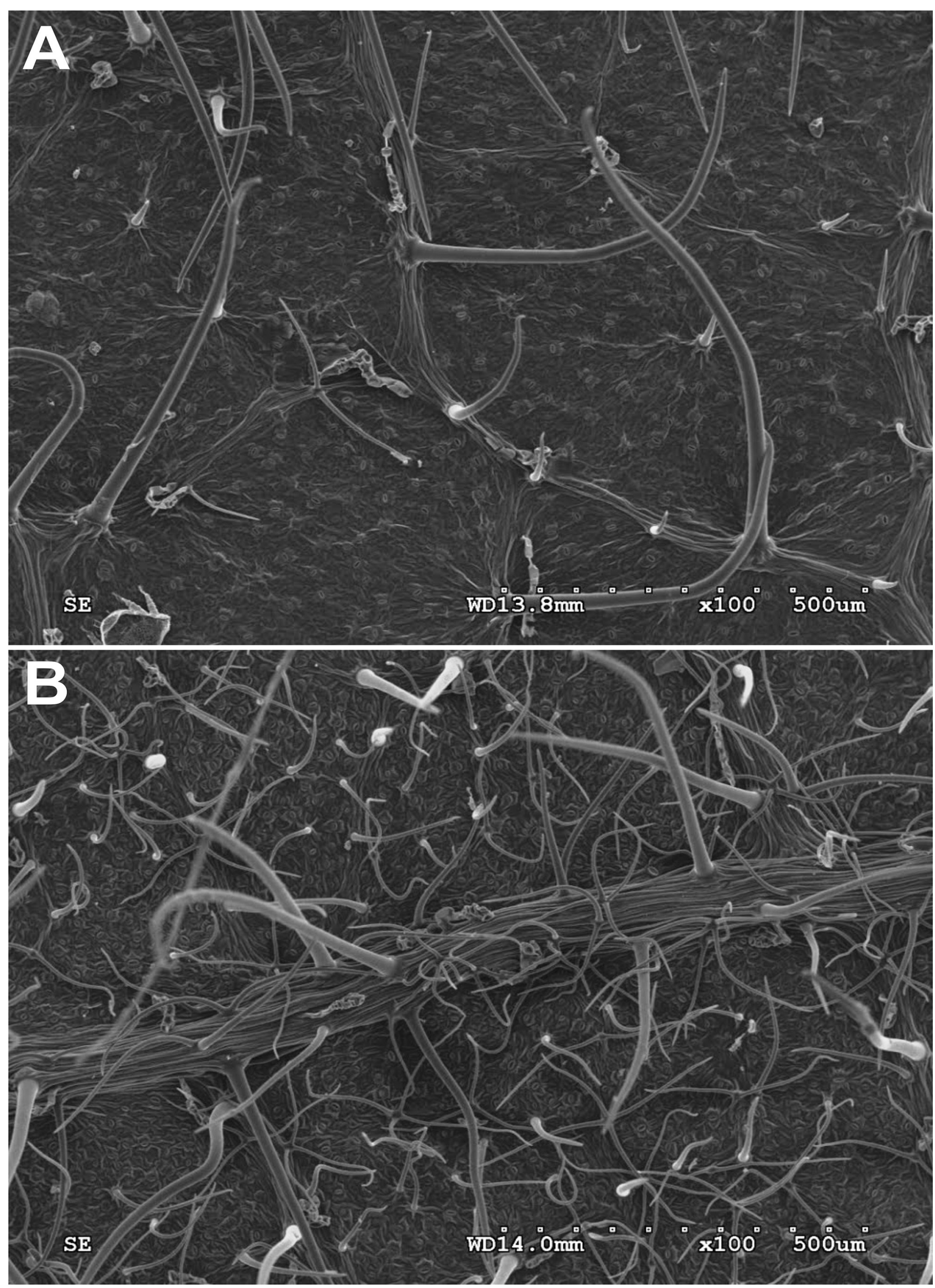

Fig. 2. Rubus limitaneus (from the holotype). Abaxial leaf surface (SEM micrographs, photo D. Tomaszewski) 


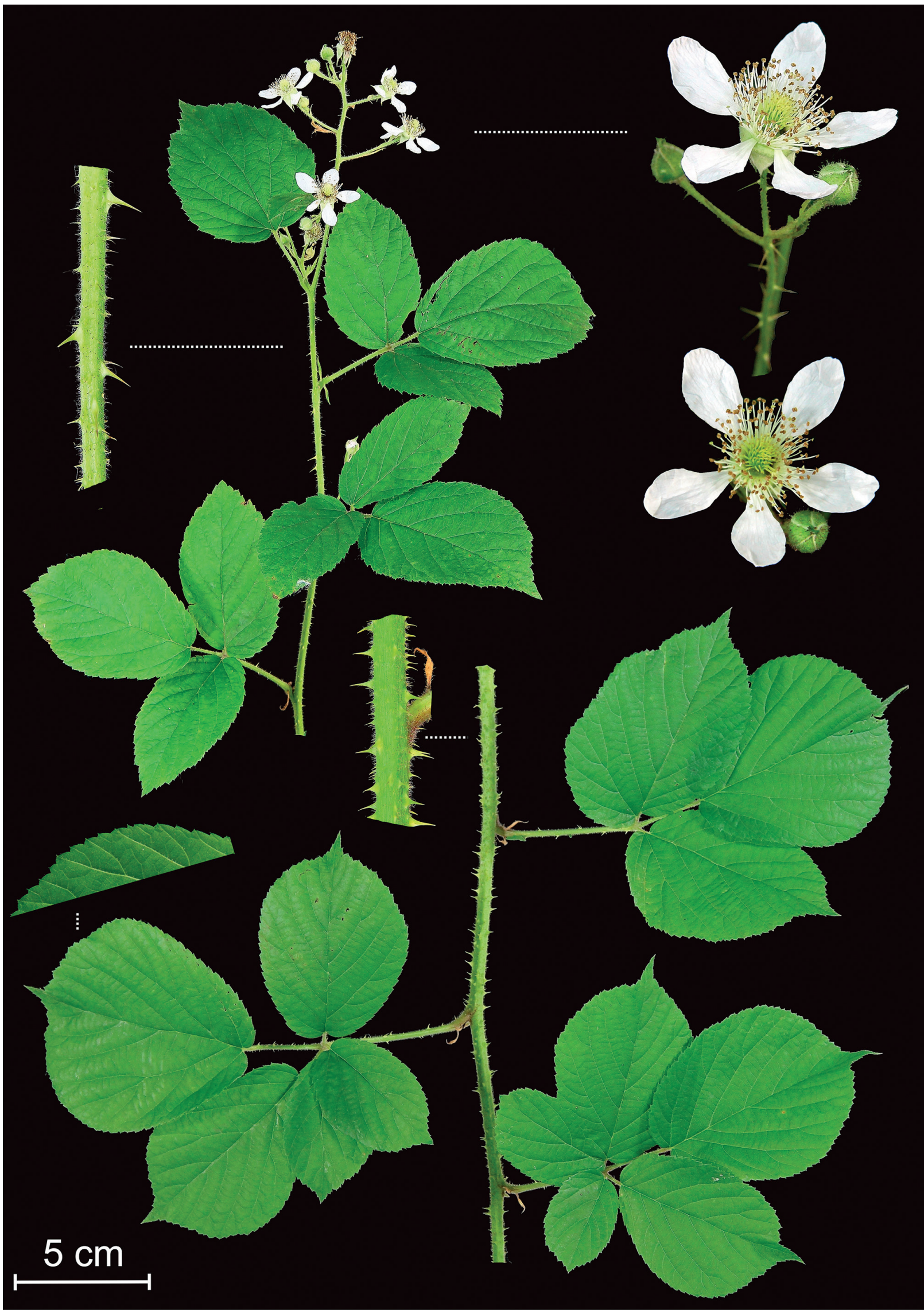

Fig. 3. Rubus limitaneus. From the plant cultivated in the Dendrological Garden of the University of Life Sciences, Poznań (photo W. Danielewicz) 


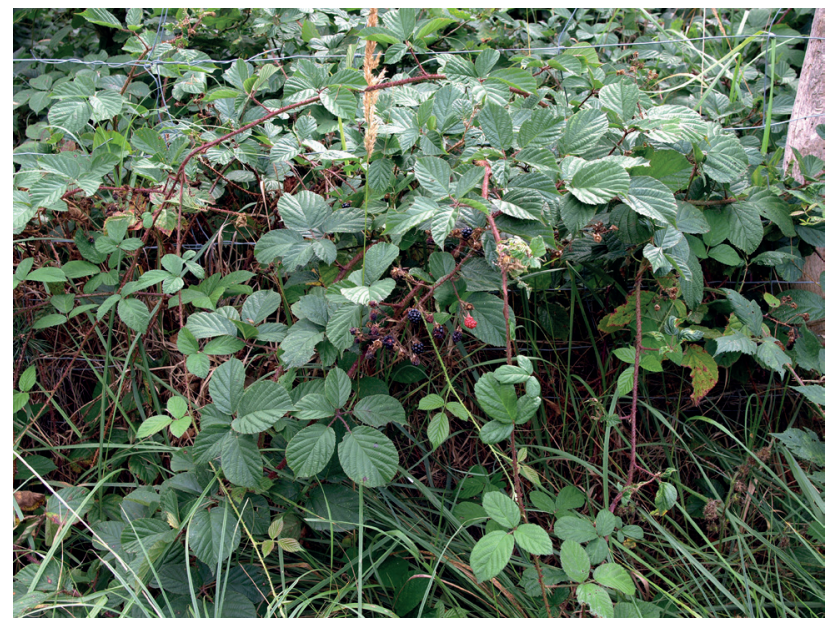

Fig. 4. Rubus limitaneus. Luxuriant specimen at the margin of the young pine plantation, August 2013 (photo P. Kosiński)

Rubus limitaneus grows usually in artificial forests established on former cropland. These are most of- ten pine plantations, no more than 80-100 years old, which are rather loosely stocked with poor undergrowth and ground-flora (Fig. 6). It can also be found along forest roadsides, and on the fringes of young woods. It rarely grows at beech forests' margins and in larger clearings. In some places it is extremely common and forms an almost single-species undergrowth. It is often accompanied by. R. idaeus L., $R$. gracilis J. Presl \& C. Presl and R. plicatus Weihe \& Nees.

\section{Herbarium specimens and field observations}

AC-22. $2 \mathrm{~km} \mathrm{SW}$ of Krzywin, clearing in an open beech forest. $53^{\circ} 04^{\prime} 30^{\prime \prime} \mathrm{N}-14^{\circ} 25^{\prime} 55^{\prime \prime}$ E, 13 July 2011, col. T. Maliński \& J. Zieliński in Maliński 22/11, 23/11, 24/11; AC-22. $2.5 \mathrm{~km}$ SSW of Krzywin, pine forest, 5303'55' $\mathrm{N}-1^{\circ} 27^{\prime}$ E, 13 July 2011, col. T. Maliński \& J. Zieliński in Maliński 25/11; AC-22.

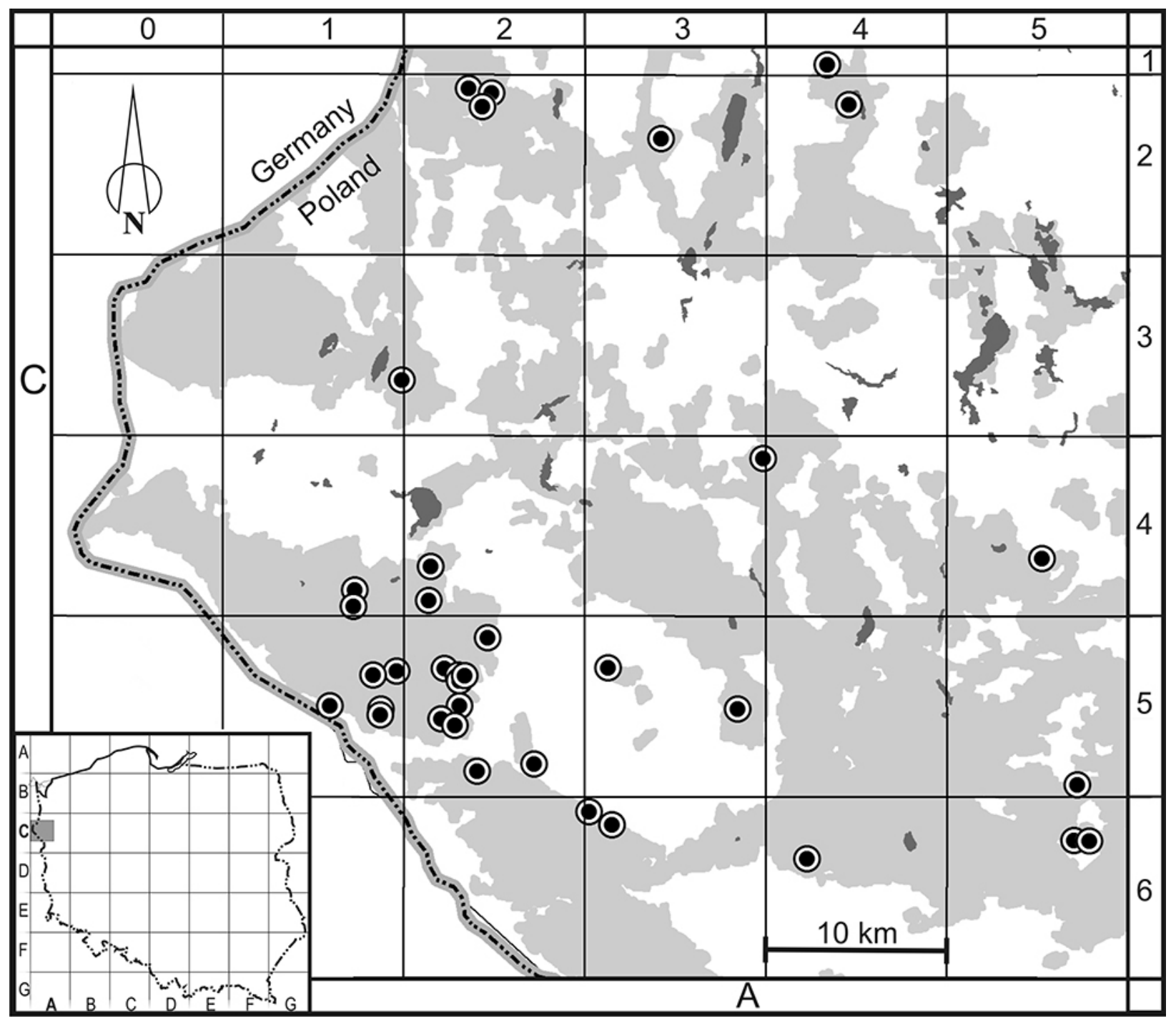

Fig. 5. Distribution of Rubus limitaneus 


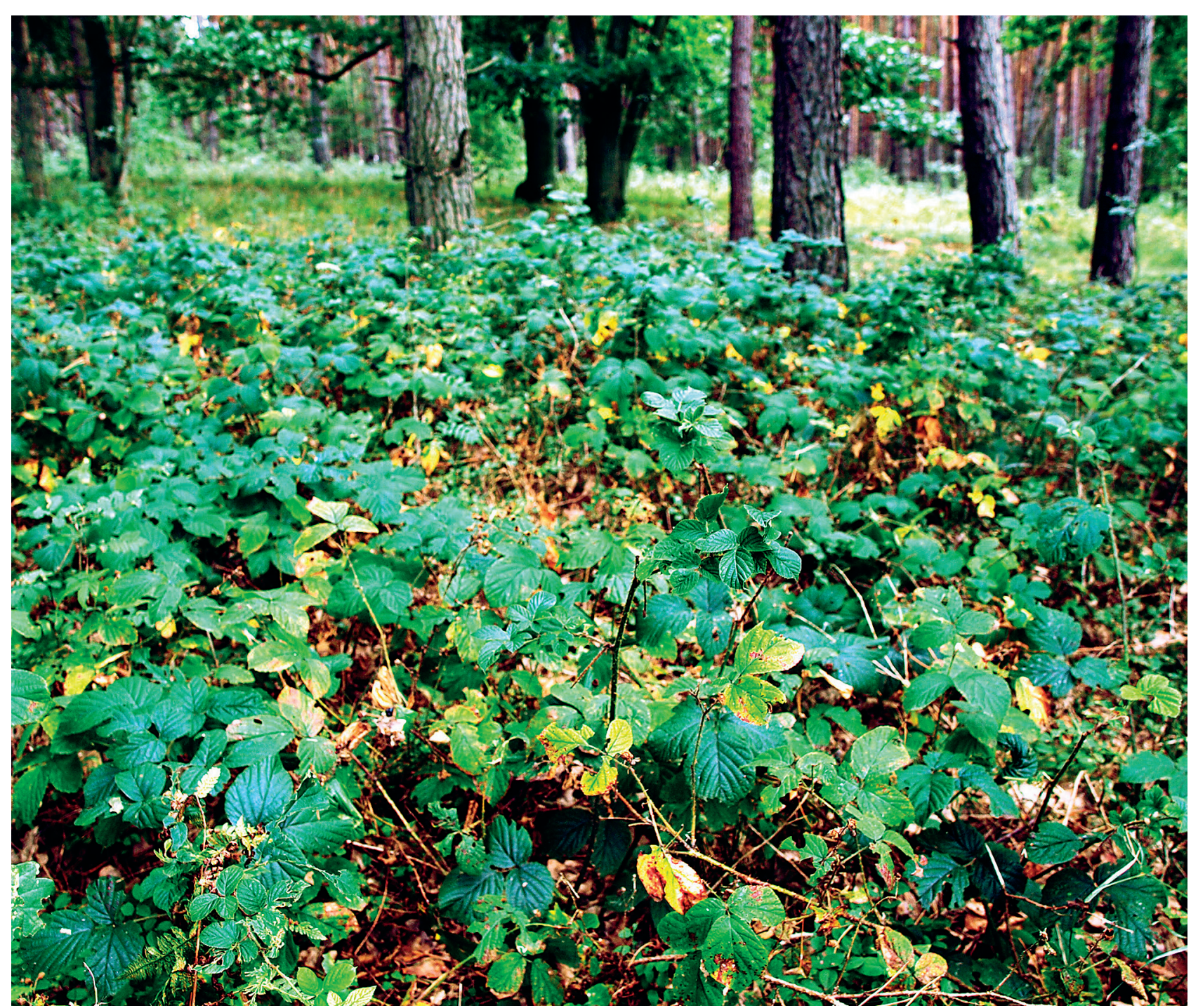

Fig. 6. Rubus limitaneus under the canopy of the artificial pine forest established on former farmland near the Sosny village, August 2013 (photo P. Kosiński)

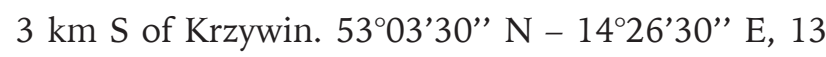
July, 2011, obs. T. Maliński \& J. Zieliński in Maliński; AC-22. $2 \mathrm{~km}$ NE of Rynice, pine forest, 330.'05" N - 14²6'54" E, 13 July 2011, col. T. Maliński \& J. Zieliński in Maliński 25/11; AC-31. 1.5 km NE of Mętno Małe, mixed forest, $52^{\circ} 55^{\prime} 30^{\prime \prime} \mathrm{N}-14^{\circ} 23^{\prime} \mathrm{E}, 8 \mathrm{Au}-$ gust 2004, col. T. Maliński 55/04; AC-41. Road from Stare Łysogórki to Moryń, pine forest, 52 49’10" N - 14²1'20” E, 29 August 2003, col. T. Maliński 39/03; AC-41. $6 \mathrm{~km} \mathrm{NE}$ of Gozdowice, pine forest, $52^{\circ} 48^{\prime} 40^{\prime \prime} \mathrm{N}-14^{\circ} 21^{\prime} 10^{\prime \prime} \mathrm{E}-, 7$ August 2004, col. T. Maliński 41/04; AC-42. 3 km SWW of Bielin, young pine forest, $52^{\circ} 49^{\prime} \mathrm{N}-14^{\circ} 25^{\prime} \mathrm{E}, 6$ August 2004, col. T. Maliński 28/04; AC-42. Between Moryń \& Mieszkowice, pine forest, 52 $50^{\circ} \mathrm{N}-14^{\circ} 25^{\prime} \mathrm{E}, 29$ August 2003, col. T. Maliński 41/03, 41a/03; AC-43. 3 km SE of Piaseczno, pine forest, 52 $53^{\prime} 50^{\prime \prime} \mathrm{N}-14^{\circ} 41^{\prime}$ E, 25 July 2006, col. T. Maliński \& P. Kiciński in Maliński 16/2006; AC-45. $2 \mathrm{~km}$ SSW of Stawy, mixed forest, $52^{\circ} 51^{\prime} 20^{\prime \prime} \mathrm{N}-14^{\circ} 55^{\prime}$ E, 26 July 2006 , col. T.
Maliński \& P. Kiciński in Maliński 24/06; AC-51. By the way from Gozdowice to Czelin, cross-road to Błeszyn, pine forest, $52^{\circ} 45^{\prime} 40^{\prime \prime} \mathrm{N}-14^{\circ} 20^{\prime} 30^{\prime \prime} \mathrm{E}$, 26 August 2003, col. T. Maliński \& J. Zieliński in Maliński 7/03; ibidem, 52 $45^{\prime} 30^{\prime \prime} \mathrm{N}-14^{\circ} 23^{\prime} \mathrm{E}$, col. T. Maliński \& J. Zieliński in Maliński 8/03; AC-52. Between Mieszkowice and Czelin, pine-birch greenwood, 52 $2^{\circ} 46^{\prime} 05^{\prime} \mathrm{N}-14^{\circ} 27^{\prime}$ E, 27 August 2003, col. T. Maliński \& J. Zieliński in Maliński 14/03, 15/03; ibidem, 5245’30” N 14²6’ E, col. T. Maliński \& J. Zieliński in Maliński 16/03; AC-52. C. $4 \mathrm{~km} \mathrm{~W}$ of Mieszkowice, pine forest, $52^{\circ} 46^{\prime} 40^{\prime \prime} \mathrm{N}-14^{\circ} 26^{\prime} 45$ E", 27. August 2003, col. T. Maliński \& J. Zieliński in Maliński 11/03; ibidem, 52 ${ }^{\circ} 46^{\prime} 50^{\prime \prime} \mathrm{N}-14^{\circ} 26^{\prime} 40^{\prime \prime}$ E, col. T. Maliński \& J. Zieliński in Maliński 9/03; AC-52. By the way from Kłosów to Namyślin, 52 $44^{\circ}$ $\mathrm{N}-14^{\circ} 27^{\prime} 05^{\prime \prime}$ E, 27 August 2003, col. T. Maliński \& J. Zieliński in Maliński 18/03; AC-52. 2.5 km NW of Mieszkowice, pine forest, $52^{\circ} 48^{\prime} \mathrm{N}-14^{\circ} 28^{\prime} \mathrm{E}, 6$ August 2004, col. T. Maliński 24/04, 25/04; AC-53. 
$3 \mathrm{~km} \mathrm{~S}$ of Zielin, pine forest, $47^{\circ} 20^{\prime} \mathrm{N}-14^{\circ} 34^{\prime} 52$ E”, 26 July 2005, col. T. Maliński 14/05; AC-53. 5 $\mathrm{km}$ NW of Dębno, pine forest, $52^{\circ} 46^{\prime} 20^{\prime \prime} \mathrm{N}-14^{\circ} 40^{\prime}$ E, 27 July 2005, col. T. Maliński 32/05; AC-55. C. $4 \mathrm{~km} \mathrm{~N}$ of Sosny village, pine forest, $52^{\circ} 44^{\prime} 40^{\prime \prime} \mathrm{N}-$ $14^{\circ} 57^{\prime} 20^{\prime \prime}$ N, 22 September 2005, col. T. Maliński \& J. Zieliński in Maliński 48/05; AC-63. Between Boleszkowice and Porzecze, pine forest, $52^{\circ} 43^{\prime} \mathrm{N}-$ 14³3’30” E, 27 August 2003, col. T. Maliński \& J. Zieliński in Maliński 25/03; AC-63. Between Cychry and Dębno, pine forest, 52 $42^{\prime} \mathrm{N}-14^{\circ} 41^{\prime} 30^{\prime \prime} \mathrm{E}, 28$ August 2003, col. T. Maliński 33/03, 33a/03; AC-63. Between Chwarszczany and Boleszkowice, wayside thickets in pine forest, $52^{\circ} 42^{\prime} 40 \mathrm{~N}^{\prime \prime}-14^{\circ} 34^{\prime} 40^{\prime \prime} \mathrm{E}$, 27 August 2003, col. T. Maliński \& J. Zieliński in Maliński 22/03; AC-64. C. $3 \mathrm{~km}$ NE of the village of Kamionka, 52 $42^{\prime} \mathrm{N}-14^{\circ} 44^{\prime} 20^{\prime \prime}$ E, 27 November 2005, col. T. Maliński 36/05; AC-65. $0.5 \mathrm{~km}$ SE of Sosny, wild in an old park, 52 $43^{\prime} \mathrm{N}-14^{\circ} 57^{\prime} 20^{\prime \prime} \mathrm{E}$, 22 September 2005, col. T. Maliński \& J. Zieliński, in Maliński 47/05; AC-65. Ca $1 \mathrm{~km}$ E of Sosny, broadleaf forest margin, $52^{\circ} 42^{\prime} 58,5^{\prime \prime} \mathrm{N}-14^{\circ} 58^{\prime} 03,9^{\prime \prime} \mathrm{E}$, 4 September 2013,col. P. Kosiński, T. Maliński \& J. Zieliński in Maliński 3/13.

\section{Acknowledgements}

The authors are grateful to Dr D. Tomaszewski for SEM micrographs (Fig. 2), to Dr Władysław Daniele- wicz for the photographs used in the compilation of the figure 3 , and to anonymous reviewers for valuable comments. The study was supported by the Ministry of Higher Education, Poland (project number $121 / \mathrm{L} / 59 / \mathrm{W})$.

\section{References}

Holzfuss E. 1901. Neue Brombeeren aus Pommern. Allgemeine Botanische Zeitschrift 7: 118-119.

Holzfuss E. 1903. Rubus villicaulis var. validus mh. Allgemeine Botanische Zeitschrift 9: 27-28.

Holzfuss E. 1909. Botanische Nachrichten und Neuheiten aus Pommern. Allgemeine Botanische Zeitschrift 15: 85-87.

Holzfuss E. 1916. Brombeeren der Provinz Pommern. Allgemeine Botanische Zeitschrift 22: 116-127.

Holzfuss E. 1917. Brombeeren der Provinz Pommern. Allgemeine Botanische Zeitschrift 23: 12-17.

Holzfuss E. 1930. Botanische Novitäten der Genera Rubus und Rosa. Feddes Repertorium 28: 204-207. http://dx.doi.org/10.1002/fedr.4870282205

Zając A. 1978. Atlas of distribution of vascular plants in Poland (ATPOL). Taxon 27: 481-484. http:// dx.doi.org/10.2307/1219899

Zieliński J. 2004. The genus Rubus (Rosaceae) in Poland. Polish Botanical Studies 16: 1-300. 